\title{
KRITIK HOSSEIN NASR ATAS PROBLEM SAINS DAN MODERNITAS
}

\author{
Moh. Anas \\ Universitas Brawijaya Malang \\ mohanas@gmail.com
}

\begin{abstract}
Abstrak
Sains Barat Modern, yang menjadi komponen utama penyokong tumbuhnya modernitas, telah kehilangan rujukan transendental. Hilangnya rujukan kepada yang Mutlak ini disebabkan adanya pemisahan antara sains dan agama sejak munculnya zaman renaissance (pencerahan) yang pada akhirnya bermetamorfosis menjadi modernitas. Peristiwa tersebut dimaknai sebagai peristiwa pemberontakan manusia terhadap kekuasaan Ilahi. Modernitas sebagai anak kandung renaissance lahir dari spirit pemberontakan tersebut. Sebuah zaman yang mempunyai karakter antroposentris, memisahkan antara kontemplatif dan aksi, serta menghilangkan aspek transendental atau spiritual. Akibatnya, dunia modern telah dilanda tragedi dan krisis, seperti krisis spiritual, krisis lingkungan, kecemasan terhadap bahaya perang dan lain-lain.
\end{abstract}

Abstract

Modern Western science, which became a major proponent of the growth component of modernity, has lost its transcendent reference. Reference to the absolute loss is due to the separation between science and religion since the advent of Renaissance (enlightenment), which eventually morphed into modernity. These events were interpreted as the events of man's rebellion against divine authority. Modernity as a child of the renaissance of the spirit of rebellion was born. An era that has anthropocentric character, split between contemplative and action, as well as eliminating the transcendental or spiritual aspects. As a result, the modern world has been hit by tragedy and crisis, such as spiritual crisis, environmental crisis, anxiety about the dangers of war and other

Keyword: Transenden; Immanen; Sains; Modernitas; Neo-Sufistik dan seterusnya 


\section{A. Pendahuluan}

Kehidupan masyarakat sekarang ini menjadi gambaran yang paling kongkrit dari kejatuhan sejarah manusia. Melalui berbagai sistem kehidupan yang diciptakannya sendiri dalam bidang sosial, budaya, politik, ekonomi dan seterusnya, ternyata justru membawa persoalan tersendiri. Jika dirunut lebih jauh, persoalan ini tumbuh dan berawal dari pemutlakan kebenaran sains dan teknologi, sehingga menafikan kebenaran yang lain, termasuk kebenaran agama yang dianggap tidak dapat diverifikasi secara empiris dan batas-batas ilmiah. Teknologi yang bersifat operasional, efektif, dan otomatis tersebut telah membentuk pola pikir manusia, sehingga rasio manusia modern bersifat instrumental atau yang di sebut dengan rasionalitas teknologis. ${ }^{1}$

Kondisi manusia modern tersebut digambarkan oleh Erich Fromm seperti manusia robot, yakni manusia supercerdas yang mempunyai kemampuan paripurna, namun kehilangan cita rasa kemanusiaan dan tanpa kekayaan spiritual. Manusia mengalami keterasingan terhadap diri dan lingkungannya. Tragisnya, dalam keterasingan ini manusia berperan sebagai penyebab sekaligus korban yang harus menanggung akibatnya. ${ }^{2}$

Sebagai sebuah proses sejarah, modernitas merupakan suatu hal yang tak terelakkan. Namun, modernisasi yang berjalan di Barat justru telah membawa dampak negatif terhadap terjadinya kerancuan dan penyimpangan nilai-nilai. ${ }^{3}$ Manusia modern kian dihinggapi rasa cemas dan ketidakbermaknaan dalam hidupnya. Mereka telah kehilangan visi keilahian atau dimensi

${ }^{1}$ Yang dimaksud dengan rasio instrumental atau rasionalitas teknologis adalah akal budi yang mengarah pada kegunaan, yakni rasio yang berfungsi sebagai alat yang netral guna mengoperasikan sebuah sistem. Orang modern mengandaikan begitu saja kebenaran rasio macam ini dengan menganggap yang "rasional" itu operasional, efektif, efesien, dapat diotomatisasikan, dan dapat dimanipulasi. Dengan begitu, rasio dipisahkan dari dimensi praksis, rasio tidak lagi mengandung unsur-unsur moral dan unsur subjektif manusia. Lihat Sindhunata, Dilema Usaha Manusia Rasional: Kritik Masyarakat Modern oleh Horkheimer dalam Rangka Sekolah Frankfurt, (Jakarta: Gramedia, 1983), h. 93.

${ }^{2}$ Erich Fromm,, Masyarakat yang Sehat, terj. TB. Murjianto, (Jakarta: Yayasan Obor, 1995), h. 28

${ }^{3}$ Azyumardi Azra, "Pasca Modernisme, Islam dan Politik", dalam Ulumul Qur'an, No. 1, Vol. V, tahun 1994, h. 8 
transendental, karena itu mudah dihinggapi kehampaan spiritual. Akibatnya, manusia modern menderita keterasingan (alienasi), baik teralienasi dari dirinya sendiri, dari lingkungan sosialnya maupun dari Tuhannya.

Nasr sendiri melihat kebudayaan modern di Barat (sebagai representasi) sejak zaman renaisance merupakan eksperimen yang gagal karena mereduksi seluruh kualitas kepada kuantitas, atau mereduksi seluruh yang esensial dalam pengertian metafisika kepada pengertian materiil dan subtansial dalam pengertian fisik. $^{4}$

Sebelum membicarakan padangan Nasr tentang problem modernitas dan sains, kiranya penting untuk diulas gagasan Nasr tentang Islam tradisi, sebab pendekatan Islam "tradisi" ini digunakan Nasr dalam semua aspek keilmuan yang ditekuninya. Seperti sains, filsafat, teologi sufisme, seni, musik, arsitektur, dan bidang-bidang lainnya. Sehingga kiranya dapat dikatakan bahwa tema "tradisi" menjadi titik sentral sekaligus menjadi landasan pemikiran pemikiran Nasr.

Tradisi yang dimaksud Nasr disini bukan dalam arti kebiasaan, adat-istiadat atau transmisi ide-ide serta motif-motif secara otomatis dari suatu generasi kepada generasi selanjutnya, akan tetapi yang dimaksudkan tradisi adalah serangkaian prinsipprinsip yang telah diturunkan dari langit, yang ketika diturunkan itu ditandai dengan suatu manifestasi Ilahi. ${ }^{5}$

Tradisi dalam pengertian ini bisa berarti addin dalam pengertian seluas-luasnya yang mencakup semua aspek agama dan percabangannya; bisa pula al-Sunnah, yaitu apa yang sudah menjadi tradisi; dan juga bisa berarti as-silsilah, yaitu rantai yang mengaitkan setiap periode kepada sumber seperti tampak dalam sufisme. ${ }^{6}$

Dalam prakteknya, Islam Tradisional adalah sebuah aliran

${ }^{4}$ Hossein Nasr, Spritualitas dan Seni Islam, terj. Sutejo, (Bandung: Mizan, 1993), h. 38

${ }^{5}$ Hossein Nasr, Islam dan Nestapa Manusia Modern, terj. Anas Mahyuddin, (Bandung : Pustaka, 1983), h. 79.

${ }^{6}$ Hossein Nasr, Islam Tradisi di Tengah Kancah Dunia Modern, terj. Luqman Hakim, (Bandung: Pustaka, 1994), h.3. 
yasng menerima beberapa fase Islam: pertama, menerima al-Qur'an sebagai Kalam Tuhan baik kandungan maupun maknanya. Kedua, menerima komentar-komentar tradisional mengenainya. Ketiga, menafsirkan al-Qur'an tidak berdasar makna literalnya. Keempat, menerima koleksi ortodoks shahih yang enam dan empat buku Syi'ah. Kelima, mempertahankan syari'ah sebagai hukum Ilahi. Dan keenam, membuka peluang ijtihad dan mengakui prinsip-prinsip legal tradisional seperti qiyas, ijma' dan istihsan. ${ }^{7}$ Beberapa hal dari tradisi dan Islam tradisional itulah yang menjadikan aliran ini berbeda dengan Islam Fundamentalis dan Islam Modernis. ${ }^{8}$

\section{B. Pandangan Dunia (Ru'yah al-'A m)Yang Integral}

Dalam pandangan Nasr, setiap agama yang asli telah mencoba menyampaikan keesaan Tuhan dan berbagai aspek realitas yang tak terbatas-Nya, beberapa diantaranya menekankan dan menggambarkan tentang ajaran keseluruhan watak Tuhan yang memungkinkan bahasa manusia memahaminya. Bagi Nasr, Allah merupakan Realitas Tertinggi, Tuhan sekaligus Ketuhanan, Transenden sekaligus Imanen, sangat jauh sekaligus dekat dengan manusia, Agung sekaligus pemurah. Dia absolut, tidak terbatas dan sumber segala rahmat. Dia adalah asal mula dan akhir segala sesuatu. ${ }^{9}$ Definisi tentang Tuhan ini senantiasa tetap meyakini akan keberadaan Tuhan yang bersifat meta-empiris, karenanya Nasr tetap beragaggapan bahwa Tuhan hanya dapat dijangkau dengan meta-bahasa, yakni apa yang oleh kaum mistik disebut "the language of silent". Menurut Komarudin Hidayat, manusia yang mampu menjangkaunya adalah manusia yang mengoptimalkan peran intelek (aql), bukan rasio, secara maksimal dalam rangka menangkap jejak-jejak sifat Tuhan. ${ }^{10}$

Sementara diskusi tentang manusia dapat dilihat dalam perspektif Islam. Menurut Nasr, manusia adalah khalifah (wakil) Allah di muka bumi dan sekaligus abdi-Nya ('abd). Kedudukannya bersama-sama membentuk sifat fundamental baginya. Sebagai

${ }^{7}$ Tbid, h. 4-5.

${ }^{8}$ Lebih lanjut baca Hossein Nasr, Ibid, h. 9-12 dan 83.

${ }^{9}$ Hossein Nasr, Ibid., h. 34

${ }^{10}$ Dalam Budhy Munawar Rachman (ed.) Kontekstualisasi Doktrin Islam Sejarah, (Jakarta: Paramadina, 1994), h. 34-35. 
abdi-Nya, manusia harus patuh kepada kehendak-Nya. Dia harus pasif secara total vis-a-vis kepada kehendak Tuhan, menerima dariNya petunjuk untuk kehidupannya serta melaksanakan KehendakNya menurut sunnatullah. ${ }^{11}$ Menurut Nasr, posisi manusia bersifat pasif apabila dia sebagai hamba-Nya, akan tetapi dia juga bersifat aktif jika ia berperan sebagai wakil Tuhan di bumi. Singkatnya, manusia adalah jembatan antara langit dan bumi, instrumen yang menjadi perwujudan dan kristalisasi kehendak Tuhan di bumi. Menurut Nasr, konsep manusia dalam doktrin tradisional mencerminkan aneka dimensi yang penuh dengan tawaran hirarki, mulai anatomi diri sampai dengan variasi gender dan ras. Namun demikian, titik pangkalnya terletak pada konsep tentang manusia promordial sebagai sumber refleksi total tentang Tuhan, dan realitas yang merupakan modal dasar yang memuat kemungkinankemungkinan eksistensi alam itu sendiri. Adapun manusia biasa, bukan primordial man, diistilahkan Nasr dengan manusia duniawi (terrestrial man). Karaktersitik manusia primordial ini meniscayakan bahwa realitas manusia pada prinsipnya memiliki tiga segi fundamental. Pertama, dengan merujuk pada Nabi-Nabi dan wali-wali besar, konsep manusia promordial pertama-tama merupakan pola dasar dari realitas jagat raya. Lalu yang kedua, manusia primordial merupakan media pewahyuan yang turun ke dunia, dan akhirnya ia adalah model sempurna bagi kehidupan spiritual dan pemancar pengetahuan esoterik. Tampilnya manusia primordial pada umumnya menunjukkan sekaligus bahwa manusia pada umumnya berkemampun untuk menggunakan wahyu, tradisi dan akhirnya kesakralan. Artinya, apa yang diwahyukan oleh kepadanya secara potensial dapat diaktualisasikan oleh setiap manusia, manusia-bumi yang menghadapi dunia nyata dan mampu menuju jalan kesempurnaan, sekaligus menemukan hakekat dirinya.

Sementara mengenai alam, Nasr melihatnya sebagai teofani, di samping juga diibaratkan sebagai teks, alam bagaikan selembar bahan penuh lambang-lambang yang harus 'dibaca' menurut maknanya. Al-Qur'an adalah padanan teks tersebut dalam katakata manusia; kalimat-kalimatnya disebut ayat ('tanda-tanda')

${ }^{11}$ Hossein Nasr, Islam Tradisi..., h. 40 
persis seperti fenomena alam. Alam dan al-Qur'an menegaskan kehadiran dan pemujaan Tuhan: "Kami akan memperlihatkan kepada manusia tanda-tanda kekuasaan Kami di segenap ufuk dan pada diri-diri mereka sendiri sehingga jelas bagi mereka bahwa alQur'an itu adalah kebenaran". ${ }^{12}$

Demikian gagasan Nasr tentang kosmologi yang mencakup konsep tentang Tuhan, Manusia dan Alam. Trilogi ini harus berjalan secara seimbang, tanpa menghilangkan salah satu kutub diantara ketiganya. Hilangnya kutub Tuhan, misalnya seperti yang terjadi di Barat-Eropa, akan berakibat terjadinya krisis spiritual yang tengah terjadi. Sementara hilangnya kutub alam, seperti yang terjadi di dunia Islam, juga mengakibatkan tidak berkembangan ilmu pengetahuan dan sains. Atas dasar inilah, ketiga kutub tersebut harus berjalan secara integral dan seimbang dalam rangka membangun peradaban yang madani.

\section{Sejarah Sains dan Hilangnya Rujukan Transendental}

Pembicaraan tentang pemikiran Nasr tidaklah lengkap bila tanpa menyinggung pandangannya tentang kedudukan sains dalam Islam. Dan bidang inilah yang semula menjadi keahlian profesionalnya. Semua gelar formal yang diperolehnya di MIT dan Harvard berkenaan dengan sejarah sains (Islam) ini. Sejauh menyangkut bidang tersebut, setidaknya ia menulis karya-karya penting; Islam Science: An Illustrated Study (1976), Science and Civilization In Islam (1967), dan Knowledge and The Sacred (1989), yang sebenarnya merupakan karya menyangkut metafisika.

Secara historis, pada mulanya sains tradisional memang sudah berkembang jauh sebelum Yunani, berbagai mazhab sains tradisional tersebut adalah India, Cina, Babylonia, Mesir dan seterusnya. Suatu prestasi yang luar biasa dicapai oleh para ilmuwan muslim yang mampu menyerap berbagai sains tradisional tersebut, inilah yang sangat membedakannya, tentu dari segi capaian tingkat pengetahuan dari tradisi sains di Barat. Islam mewarisi aspek-aspek tertentu dari warisan ilmiah dunia Mediterania yang tidak sampai di tangan Yunani, Islam menyerap hampir seluruh himpunan sains Aristotelian, termasuk berbagai

${ }^{12}$ Al-Qur'an. Surat 41: 53. 
karya-karya komentator-komentator Alexandria berikut satelitsatelitnya di Pergamon, dan segi-segi lebih esoteris sains Yunani yang berkaitan dengan Pythagoreanisme dan Hermetisisme.

Menurut Nasr, tidak seluruh sains kuno sampai ke dunia Barat Kristen. Sebagian besar warisan Aristotelian, Hermetisisme dan Pythagoreanisme belum diketahui di Eropa hingga milenium kedua Masehi. Karena itulah warisan sains Barat dan sains Islam tidak sama. Hanya saja, fakta menunjukkan bahwa keduanya sama-sama mewarisi sains-sains dari dunia yang sama berikut cara pandangnya terhadap tatanan alam, konsep, hukum kausalitas, dan kosmologi umum yang diambil dari sumber-sumber serupa, sekalipun masing-masing pihak mengembangkan konsep-konsep warisan ini secara berbeda dan berlainan. ${ }^{13}$

Karena Kristen dan Islam termasuk rumpun agama yang sama dalam mazhab monoteisme, maka sebetulnya pada mulanya sains berkembang di Barat Kristen berada sepanjang garis yang sama dalam peradaban sains Islam tradisional. Paralelisme ini terutama disebabkan oleh kesamaan metode, gagasan-gagasan kosmologi dan filosofis tentang materi, gerak, dan sebagainya serta tujuan sains-sains alam sebagai sarana untuk menemukan hikmah Tuhan yang ada dalam sains Islam. Hal ini terbukti di abad pertengahan muncul Mazhab Chartes, Albertus Magnus, Robert Grossetetes, Roger Bacon, Raymond Lull, dan seterusnya mengembangkan sains yang memiliki sifat, metode, dan lingkup yang sama dengan sains-sains di kalangan kaum Muslimin.

Namun, pada perkembangannya, nominalisme di Barat meraih kemenangan telah mengalahkan kelompok teolog, sementara filsafat Kristen sendiri secara berangsur-angsur mengalami kemerosotan dan kemunduran. Suatu proses pemisahan antara agama sains terjadi dalam kurun waktu tersebut. Revolusi ilmiah ini ditandai dengan munculnya Descartes, Galileo dan akhirnya Newton. Dalam periode inilah terjadi sebuah transformasi makna sains yang tidak bisa disamakan atau diulangi secara independen di dunia Islam.

${ }^{13}$ Madjid Fakhri, Sejarah Filsafat Islam, terj. Mulyadi Kartanegara, (Jakarta: Pustaka Jaya, 1980), h. 31-49. 
Menurut Nasr, astronomi dan fisika modern dari seorang Galileo atau Newton berpijak pada pandangan tentang kosmos yang sudah tersekularisasikan, reduksi atas alam ke dalam tataran kuantitas yang kemudian bisa ditangani dan ditanggulangi secara matematis serta pemisahan secara menyeluruh antara subyek yang mengetahui dan obyek yang diketahui berdasarkan dualisme Cartesian. Sains baru benar-benar telah lahir, sebuah sains yang menemukan banyak hal dalam bidang kuantitas, tetapi mengorbankan pandangan dunia tradisional dan mengabaikan dimensi spiritual alam, dan buah pahitnya benar-benar dirasakan kini. ${ }^{14}$

Bertolak belakang dengan berbagai transformasi yang terjadi di Barat, di dunia Islam, karakter sakral ciptaan Tuhan senantiasa mendominasi cakrawala intelektual manusia. Berbagai macam sains-alam simbolis selama dipaparkan abad-abad sebelumnya sejak kurun masa Jabir bin Hayyan hingga Suhrawardi terus dikembangkan, sementara sains-sains matematika dan fisika tetap dikaji dan ditelaah di tengah-tengah tumpukan sains simbolis dan di bawah prinsip-prinsip metafisika dan kosmologi yang diperoleh dari wahyu al-Qur'an.

Titik berangkat Nasr dalam bidang ini adalah bahwa sains, ilmu pengetahuan dan seni dalam Islam dibangun di atas gagasan tentang tauhîd, yang menjadi inti dari wahyu Islam. Dengan demikian, menurut Nasr, seluruh seni Islam baik dalam bentuk alhamrâ' maupun masjid paris, dalam berbagai keragamannya tidak terlepas dari keesaan Tuhan (divine unity). Dalam kerangka ini, sains yang dapat disebut Islami adalah sains yang mengungkapkan "ketauhidan alam". ${ }^{15}$

Kerangka tauhîd dalam konsep Nasr tentang sains dan seni kelihatan sangat kental. Menurutnya, gagasan tentang kesatuan (tauhîd) tidak hanya merupakan presupposisi dasar sains dan seni Islam; tauhîd juga mendominasi ekspresinya. Dalam alur

${ }^{14}$ Jozef Niznik, dan John T. Sanders (ed.) Jurgen Habermas, Memperdebatkan Status Filsafat Kontemporer: Habermas, Rorty dan Kolakonsky, ter. Elly al-Fajri (Yogyakarta: Qalam, 2002), h. 3-4.

${ }^{15}$ Azyumardi Azra, “Tradisionalisme Nasr: Eksposisi dan Refleksi” dalam Ulumul Qur'an, Vol. IV, No. 4 Tahun 1993, h. 45 
ini penggambaran obyek individual akan menjadi idola jiwa yang berbahaya; ketentuan dasar seni Islam adalah abstraksi. Hanya tauhîd yang layak mendapatkan representasi; dan karena ia tak dapat direpresentasikan secara langsung, maka ia dapat disimbolisasikan meskipun harus pula hanya secara isyarat. Karena itulah seni yang sakral dalam Islam adalah seni yang abstrak. ${ }^{16}$

Lebih jauh menurut Nasr, perspektifIslamyang menyatukan (unifiying perspective) tidak pernah membenarkan terjadinya pengembangan ilmu pengetahuan dan sains secara independen satu sama lain. Sebaliknya, di dalam Islam selalu terdapat interrelasi dan hierarki ilmu pengetahuan. Sejak dari ilmu pengetahan yang menyangkut materi sampai kepada metafisika; semua ini saling berkaitan sebagi refleksi dari hakikat (reality) itu sendiri. ${ }^{17}$

Nasr berargumen bahwa, Islam membenarkan kaum muslim menyerap gagasan-gagasan dari berbagai sumber, yang secara historis asing, namun berkaitan dengannya. Hal ini khususnya dalam hubungannya dengan sains-sains alam (nature), karena kebanyakan sains kosmologi kuno -Yunani , Persia, India, Cina- sepanjang sejarah mereka selalu berupaya mengekspresikan kesatuan alam. Dengan ciri ini maka mereka dengan segera berada dalam konformitas dengan semangat Islam. Begitu terlibat kontak dengan mereka, kaum muslim segera mengadopsi sejumlah unsur dari bagian-bagian yang ada. Kaum muslim menyatukan sains-sains ini ke dalam sistem baru, yang selanjutnya berkembang selama berabad-abad menjadi bagian peradaban Islam, diintegrasikan ke dalam struktus dasar yang bersumber dari wahyu itu sendiri. ${ }^{18}$

Dalam kerangka ini, Nasr menilai bahwa sains modern tidak Islami, karena tidak bersumber dari wahyu. Di sini Nasr kembali muncul dalam warna pasca-modernismenya, dengan menyerukan orang agar mengkaji dan mengembangkan ilmu pengetahuan dan sains tradisional yang dibangun oleh ilmuwan muslim klasik, seperti Ibn Sina, Ibnu Haytam, Jabi al-Hayyan, al-Biruni dan lainlain. Gagasan Nasr ini banyak menimbulkan perdebatan perdebatan panjang di kalangan ilmuwan dan cendekiawan muslim yang

\footnotetext{
${ }^{16}$ Ibid.,

${ }^{17}$ Ibid.,

${ }^{18}$ Ibid., h. 45-46
} 
menyebutnya sebagai bentuk "Islamisasi ilmu pengetahuan".

Dari uraian beberapa pemikiran Nasr tersebut di atas, tampaklah bahwa pemikiran Nasr cukup kompleks dan terus mengalami perkembangan (kemajuan dan kematangan). Pemikiran Nasr, sebagaimana tergambar di atas, secara garis besar dapat disimpulkan bahwa persoalan tasawuf (sufisme) dan problem (krisis-krisis yang dialami) dunia modern menjadi perhatian yang sangat sentral.

\section{Kritik Nasr atas Problem Modernitas}

Nasr yang dididik dan dibesarkan dalam dua tradisi besar, sebagaimana lazimnya orang-orang Timur yang dididik di Barat, mengalami pergolakan pemikiran sebelum kemudian mengambil sikap yang jelas. Nasr akhirnya memilih dan tumbuh sebagai pengkritik Barat yang paling kritis. Pilihan sikapnya itu bisa dilacak ketika ia studi di Harvard. Ini artinya, bahwa gagasangagasannya yang berkaitan dengan dunia modern sudah terbentuk lama dan matang. Sikap kritisnya diwarisi dari filsuf Perancis Rene Guneon (1886-1951) yang menulis beberapa buku tentang situasi dunia modern dewasa ini, diantaranya; Crisis of the Modern world (di tulis tahun 1927) dan the Reign of Quality and the Sign of the Times. Karena kekagumanya atas karya tersebut, Nasr menyebutnya sebagai karya profetis. ${ }^{19}$

Dalam kapasitas dan posisinya itu, Nasr kemudian tampil memproklamirkan diri sebagai juru bicara, baik kepada dunia Timur maupun Barat. Kepada dunia Barat ia menawarkan Islam, sementara kepada dunia Timur ia memberitahukan bahwa Barat tengah mengalami kebangkrutan spiritual. ${ }^{20}$ Pemikiran kritis Nasr lebih ditujukan pada posisi manusia dalam hubunganya dengan Tuhan dan alam ciptaannya, sehingga sikap kritisnya terhadap pemikiran modern ataupun dunia modern lebih mendasar.

Kata modern dan beberapa kata jadiannya memiliki beberapa arti; moderate berarti orang moderat atau tidak ekstrim; moderator berarti penengah; modernistic berarti model baru;

${ }^{19}$ Hossein Nasr, Pengetahuan dan Kesucian, terj. Suharsono, (Yogyakarta: Pustaka Pelajar, 1997) h. 116-117

${ }^{20}$ Komaruddin Hidayat, op. cit., h. 266 
modernity berarti kemodernan; dan modernize yang berarti memodernkan. Modern juga bisa berarti kekinian, disini dan sekarang ini. Oleh karena itu, kata modern ini sangat tergantung pada konteks kata itu digunakan. Jika disebut zaman modern, maka hal itu berarti menunjukkan periode sejarah tertentu dari perjalanan manusia. Zaman sebelumnya lazim disebut sebagai zaman pra-modern atau tradisional.

Bagi Nasr, term modern tidak menunjukkan suatu keberhasilan dalam penguasaan atau dominasi atas dunia alam. Melainkan, "modern" berarti sesuatu yang dilepas (cut off) dari Yang Transenden, dari prinsip-prinsip abadi yang dalam realitasnya mengatur segala sesuatu, yang dikenal melalui pewahyuan. ${ }^{21}$ Dengan demikian, dalam pandangan Nasr istilah modern, nampaknya menunjuk pada pandangan dan cara hidup masyarakat di Barat. Barat, dimaksudkan sebagai kualitas kehidupan yang rasionalistik, kapitalistik, sekularistik, dan cenderung melepaskan pandangan keagamaan. ${ }^{22}$ Di samping itu, meski Nasr tidak bermaksud membedakan dua wilayah itu secara geografis, namun yang di maksud Barat dalam pandangan Nasr adalah suatu wilayah (geografis) yang berbeda dengan dunia Timur, Asia, China, Jepang dan India misalnya. Barat adalah dunia Eropa yang pada abad 17 mengalami masa renaissance. ${ }^{23}$

Dunia Eropa mengalami masa transformasi ketika terjadi pemberontakan terhadap doktrin agama atau wahyu (Kristen). Masa itu di kenal dengan renaisasance, yakni lahirnya kembali unsur-unsur tertentu dari paganisme Yunani-Romawi. Dalam sejarah perjalanan Barat, hal itu dimulai dari adanya revolusi sains di Italia yang kemudian menyebar ke seluruh Eropa. Revolusi sains menandai dimulainya pembalikan kultur zaman yang semula didominasi oleh doktrin langit menjadi didominasi manusia melalui ilmu. Oleh Nasr dan para pengkritik Barat, peristiwa itu dimaknai sebagai peristiwa pemberontakan manusia terhadap

${ }^{21}$ Ali Maksum, Tasawwuf sebagai Pembebasan Manusia Modern: Telaah Signifikansi Konsep Tradisionalisme Seyyed Kossein Nasr, (Surabaya: PSAPM dan Pustaka Pelajar, 2003) h. 21

${ }^{22}$ Ibid.,

${ }^{23}$ Hossein Nasr, Menjelajah Dunia Modern: Bimbingan untuk Kaum Muda Muslim, terj. Hasti Tarekat, (Bandung: Mizan, 1994), h. 2 
kehendak Ilahi. Modernitas sebagai anak kandung renaissance lahir dari spirit pemberontakan tersebut.

Pemberontakanitusemakinmenjadi,ketikaberkembangnya kesangsian Cartesian yang menyatakan Cogito Ergo Sum. Menurut Nasr, diktum tersebut menempatkan aksi kognitif ego individual dan kemerdekaan akal manusia terhadap wahyu sebagai kebenaran yang tertinggi dan menjadi fondasi eksistensi. Pernyataan cogito ergo sum berarti eksistensi yang berpikir lebih penting dari apapun. Dengan demikian, masa modern adalah masa peralihan dari pola berfikir yang teosentris ke antroposentis, dari Tuhan menuju manusia. Perubahan dari manusia budak menjadi manusia tuan bahkan mungkin manusia robot. Manusia menjadi tolak ukur dari semua yang ada

Keadaan tersebut memberi pengertian pada diri Nasr bahwa dunia modern adalah dunia yang sudah terpisah dari yang Trasenden dari prinsip-prinsip langgeng yang dalam realitas mengatur materi dan yang diberikan, maka bagi Nasr, modern bukanlah kontemporer, maju, lanjut dan berkembang, tapi merupakan lawan dari tradisi, lawan dari yang sakral dan Transenden. ${ }^{24}$

Karena dunia modern adalah dunia yang sudah lepas terpisah dari yang Trasenden, maka dunia modern bersifat sekuler. Kata sekuler sendiri berasal dari bahasa latin; speculum yang berarti "zaman", manjadi sekuler berarti di orientasikan pada zaman ini, yakni pada sekarang ini. ${ }^{25}$

Dengan kata lain, sekularisasi adalah terbebasnya manusia dari kontrol atau komitmen terhadap nilai-nilai agama. Hal ini terjadi ketika manusia berpaling dari "dunia sana" dan hanya memusatkan perhatiannya pada "di sini" dan sekarang ini. Dalam ungkapan Nasr disebut sebagai kemandirian manusia terhadap akhirat dan kebebasannya di muka bumi di luar hukum-hukum dan perintah Tuhan serta wahyu, ${ }^{26}$ atau negasi dan penyangkalan

\footnotetext{
${ }^{24}$ Hossein Nasr, Islam dan Nestapa Manusia Modern, terj. Anas Mahyuddin, (Bandung : Pustaka, 1983), h. 11.

${ }^{25}$ Bassam Tibi, Krisis Peradaban Islam Moderen, terj. Yudian W. Asmin, dkk, (Yogyakarta : Tiara Wacana, 1994), h. 167.

${ }^{26}$ Hossein Nasr, Intelektual Islam: Teologi, Filsafat dan Gnosis, terj. Suharsono
} 
terhadap sesuatu yang sakral.

Secara garis besar, dalam pengamatan Nasr, dunia sekarang ini dilanda oleh dua tragedi; satu di Barat dan lainnya di Timur. Di Barat terjadi krisis peradaban modern -yang merupakan produk Barat sendiri- paling dapat dirasakan, karena ia biasanya berkaitan dengan berbagai bentuk lingkungan hidup. Tetapi, sampai sekarang krisis itu belum terpecahkan. Bahkan, gagasangagasan yang diajukan untuk memecahkan persoalan ini menjadi faktor tambahan yang membawa kepada krisis lebih lanjut. Dalam kerangka pemecahan krisis tersebut, orang dihimbau untuk dapat mengendalikan hawa nafsu; menjadi humanis rasional. Kenyataannya, tetapi sedikit sekali yang menyadari bahwa seruan itu mustahil dijalankan selama tidak ada kekuatan rohaniah/ spiritual untuk dapat mengontrol kecenderungan yang merusak dan mengikuti hawa nafsu di dalam diri manusia.

Sementara tragedi yang terjadi di Timur pada umumnya, atau di dunia Islam khususnya, sebagian besar mengalami kesalahan-kesalahan, yang mengakibatkan kegagalan dan krisis peradaban Barat. Dunia Timur mempunyai kecenderungan kuat menjadikan Barat sebagai model yang harus diikuti, tidak sebagai case study guna mengambil pelajaran dan hikmah. Di sini Nasr mengkritik keras kebanyakan masyarakat muslim yang melakukan taqlîd buta terhadap Barat, dan secara slavish menerima segala sesuatu yang berasal dari Barat.

Paling tidak, Nasr menyebut empat karakteristik dunia modern yakni: Pertama, manusia modern bersifat antroposentris, dalam arti bahwa seluruh lokus semesta diderivikasi pada manusia. Manusia menjadi pusat yang dijadikan standar atau ukuran bagi segala sesuatu, manusia yang di maksud disini adalah aspek rasionya. Kedua, karena ukurannya manusia, maka dunia modern adalah dunia yang tidak memiliki prinsip-prinsip yang langgengabadi dan tetap serta yang lebih tinggi dari yang manusiawi. Akibat dari itu adalah timbulnya relativisme dan reduksi terhadap apa yang dihasilkannya. Standar keobyektifan hanya bisa dikenali bila menggunakan standar yang lebih tinggi. Ketiga, kehilangan

dan Jamaluddin MZ, (Yogyakarta: CIIS-Press, 1995), h. 162. 
kepekaan terhadap sesuatu yang sakral. Menurut Nasr, salah satu karakteristik mendasar pemikiran modern kini adalah tiadanya kepekaaan terhadap yang sakral. Manusia modern secara praktis dapat didefinisikan sebagai jenis manusia yang telah kehilangan kepekaan kesakralannya, dan pemikiran manusia modern juga memperlihatkan secara mencolok tiadanya kepekaan terhadap yang sakral. Ini semua disebabkan oleh paham humanisme dan sekularisme. ${ }^{27}$ Dan keempat, hilangnya aspek metafisika, ${ }^{28}$ sebuah aspek yang berbicara mengenai hal-hal yang berada di balik fisikempiris. Sebab harus diakui bahwa realitas itu bukan hanya bersifat empiris atau rasional belaka. Di antara aliran-aliran besar yang lahir dari modernisme adalah humanisme, rasionalisme, empirisme, evolusionisme, progressivisme, sosialisme dan lainlain dengan tokoh-tokohnya seperti John Locke, Berkeley, Marx dan seterusnya.

Bangunan peradaban Barat yang demikian itu telah membawa konsekuensi sendiri yang ujung-ujungnya, menurut Nasr, adalah timbulnya berbagai krisis dalam segala dimensinya. Dalam pandangan Nasr, akar dari seluruh krisis di dunia modern adalah kesalahan dalam mengkonsepsikan manusia. Peradaban dunia modrn yang ditegakkan di atas landasan konsep manusia yang tidak menyertakan hal yang paling esensial bagi manusia itulah yang menjadikan kegagalan proyek modernisme. ${ }^{29}$ Sesuatu yang paling esensial bagi manusia bagi manusia adalah dimensi spiritualnya.

Akibat cara pandang yang demikian, dunia kini telah dilanda tragedi dan krisis, seperti krisis spiritual, krisis lingkungan, kecemasan terhadap bahaya perang dan lain-lain. Pada konteks inilah dapat dipahami mengapa Nasr menawarkan sufisme, Sebab dalam sufisme terdapat dimensi spiritual yang begitu ditekankan.

\section{E. Kesimpulan}

Kritik Nasr atas modernitas terlebih dahulu dilakukan

${ }^{27}$ Hossein Nasr, «Islam dan Krisis Lingkungan”, terj. Abas al-Jauhari \& Ihsan al-Fauzi dalam Islamika, No.3, Januari-Maret, 1994, h. 10

${ }^{28}$ Hossein Nasr, Menjelajah Dunia Modern..., h. 101.

${ }^{29}$ Ibid., h. 15 
dengan menjelajahi atau merunut sejarah sains Barat. Sebab sains Barat menjadi komponen utama yang menyokong tumbuhnya modernitas. Kenyataanya, sains Barat telah kehilangan rujukan transendental, hilangnya rujukan kepada yang Mutlak ini disebabkan adanya pemisahan antara sains dan teologi, atau agama. Pemisahan dua hal ini ditandai dengan adanya Revolusi ilmiah yang memunculkan Descartes, Galileo, Newton dan seterusnya. Dalam periode inilah terjadi sebuah perubahan makna sains yang sangat berbeda dengan yang terjadi di dunia Islam. Berbeda dengan di Barat, sains yang ada di Islam secara berkelanjutan dan konsisten mendasarkan diri pada tauhid sebagai pondasi dasar segala keberadaan, meskipun, pada mulanya, sains-sains tersebut berasal dari luar tradisi Islam, seperti dari India, Babilonia, Yunani dan seterusnya namun ketika sains itu sampai ke tangan umat Islam, sains tersebut mendapat 'kesakralannya'. Ini artinya, dalam Islam tidak pernah mengenal istilah 'dikotomi' ataupun pemisahan antara agama dan sains.

Lonceng pemisahan antara sains dan agama di Barat di tandai dengan munculnya zaman pencerahan yang bermetamorfosis menjadi modernitas. Peristiwa tersebut dimaknai sebagai peristiwa pemberontakan manusia terhadap kekuasaan Ilahi. Modernitas sebagai anak kandung renaissance lahir dari spirit pemberontakan tersebut. Paling tidak, menurut Nasr, terdapat karakteristik dunia modern: Pertama, antroposentris dalam pengertian bahwa seluruh lokus semesta diturunkan pada manusia. Segala sesuatu diukur melalui standar manusia. Kedua, karena ukurannya manusia, maka dunia modern adalah dunia yang tidak memiliki prinsip-prinsip yang langgeng dan abadi. Ketiga, Manusia modern secara praktis dapat didefinisikan sebagai jenis manusia yang telah kehilangan kepekaan kesakralannya. Dan keempat, hilangnya aspek metafisika. Bangunan peradaban Barat yang demikian itu telah membawa konsekuensi sendiri yang ujungujungnya menimbulkan berbagai krisis dalam segala dimensinya. Dalam pandangan Nasr, akar dari seluruh krisis di dunia modern adalah kesalahan dalam mengkonsepsikan manusia. Peradaban dunia modern yang ditegakkan di atas landasan konsep manusia tidak menyertakan hal yang paling esensial bagi manusia, inilah 
yang menjadikan kegagalan proyek modernitas. Padahal, sesuatu yang paling esensial bagi manusia bagi manusia adalah dimensi spiritualnya. Akibat dari kesalahan itulah, dunia kini telah dilanda tragedi dan krisis, seperti krisis spiritual, krisis lingkungan, kecemasan terhadap bahaya perang dan lain-lain. Pada konteks inilah dapat dipahami mengapa Nasr menawarkan sufisme, sebab dalam sufisme itulah dimensi spiritual sangat ditekankan. [ ]

\section{Daftar Pustaka}

Ulumul Qur'an, Vol. IV, No. 4 Tahun 1993.

Ulumul Qur'an, No. 1, Vol. V, tahun 1994.

Madjid Fakhri, Sejarah Filsafat Islam, terj. Mulyadi Kartanegara, Jakarta: Pustaka Jaya, 1980.

Erich Fromm, Masyarakat yang Sehat, terj. TB. Murjianto, Jakarta: Yayasan Obor, 1995.

Ali Maksum, Tasawwuf sebagai Pembebasan Manusia Modern: Telaah Signifikansi Konsep Tradisionalisme Seyyed Kossein Nasr, Surabaya : PSAPM dan Pustaka Pelajar, 2003.

Hossein Nasr, "Islam dan Krisis Lingkungan", terj. Abas al-Jauhari \& Ihsan al-Fauzi dalam Islamika, No.3, Januari-Maret, 1994. , Intelektual Islam: Teologi, Filsafat dan Gnosis, terj. Suharsono dan Jamaluddin MZ, (Yogyakarta: CIIS-Press, 1995), h. 162.

, Islam dan Nestapa Manusia Modern, terj. Anas Mahyuddin, Bandung : Pustaka, 1983.

, Islam Tradisi di Tengah Kancah Dunia Modern, terj. Luqman Hakim, Bandung: Pustaka, 1994.

, Menjelajah Dunia Modern: Bimbingan untuk Kaum Muda Muslim, terj. Hasti Tarekat, Bandung: Mizan, 1994.

, Pengetahuan dan Kesucian, terj. Suharsono, Yogyakarta: Pustaka Pelajar, 1997.

, Spritualitas dan Seni Islam, terj. Sutejo, Bandung: Mizan, 1993.

Jozef Niznik, dan John T. Sanders (ed.) Memperdebatkan Status Filsafat Kontemporer: Habermas, Rorty dan Kolakonsky, ter. Elly al-Fajri 
Yogyakarta: Qalam, 2002.

Budhy Munawar Rachman, (ed.) Kontekstualisasi Doktrin Islam Sejarah, Jakarta: Paramadina, 1994.

Sindhunata, Dilema Usaha Manusia Rasional: Kritik Masyarakat Modern oleh Horkheimer dalam Rangka Sekolah Frankfurt, Jakarta: Gramedia, 1983.

Bassam Tibi, Krisis Peradaban Islam Moderen, terj. Yudian W. Asmin, dkk, Yogyakarta : Tiara Wacana, 1994. 